\title{
False-positive antiglobulin tests in healthy subjects and in hospital patients
}

\author{
J. FREEDMAN
}

\begin{abstract}
From the Blood Bank, St Michael's Hospital, University of Toronto, Canada and MRC Experimental Haematology Unit, St Mary's Hospital, London, UK
\end{abstract}

SUMMARY An antiglobulin reagent containing anti-IgG, $-\mathrm{C} 4 \mathrm{c},-\mathrm{C} 4 \mathrm{~d},-\mathrm{C} 3 \mathrm{c}$, and $-\mathrm{C} 3 \mathrm{~d}$ was used to test red blood cells from healthy subjects and from patients in hospital. In tests read macroscopically on opal tiles, no positive reactions were found in the healthy subjects. Positive reactions were, however, observed in $7 \%$ of the hospital patients. Further tests with monospecific reagents showed the positive reactions to be due to the presence of C4d and C3d on the red cells. All patients with positive antiglobulin reactions had serious disease, in most cases associated with abnormal antibody production or abnormal immunoglobulin levels.

The usefulness of incorporating anticomplement reagents into antiglobulin sera is currently under review, and the optimal characteristics of such polyspecific antisera are under re-assessment (Chaplin, 1973; Beck and Marsh, 1977; Lacey and Cubbin, 1977; Petz and Garratty, 1978). There is general agreement that antiglobulin sera designed for the detection of red cell sensitisation in vivo, that is, by the direct antiglobulin test, should contain anticomplement antibody-in particular, anti-C3d. There have been several reports in the literature describing false-positive reactions in direct antiglobulin testing using polyspecific antisera (Garratty and Petz, 1971; Issitt et al., 1974; Beck et al., 1976). Garratty and Petz (1976) showed that when red cells from refrigerated clots were tested, the majority of false-positive reactions (noted in up to $66 \%$ of samples tested) were due to anti-C4. Red cells from refrigerated anticoagulated samples gave negative results in direct antiglobulin tests. Stratton and Rawlinson (1974) suggested that the false-positive reactions observed may be a reflection of the potency of the anticomplement sera and that dilution of the antibody might minimise the problem. Other authors (Issitt et al., 1974; Beck et al., 1976) have shown that some false-positive reactions in direct antiglobulin testing may be due to anti-species antibodies. The following study was undertaken to estimate the frequency of false-positive direct antiglobulin reactions in healthy subjects and in random hospital patients.

Received for publication 27 March 1979

\section{Material and methods}

\section{CELLS AND SERA}

Blood samples from normal, healthy subjects were obtained from blood donors and from laboratory personnel. Blood samples from hospital patients were collected consecutively from samples submitted for routine blood counts. For EDTA samples, $4 \mathrm{ml}$ of blood were added to $6 \mathrm{mg} \mathrm{K} 2$ EDTA and mixed well. For CPD samples, $1 \mathrm{ml}$ blood was added to $2 \mathrm{ml}$ CPD solution, and for ACD samples 1 vol blood was added to $0.3 \mathrm{vol}$ ACD solution (NIH Solution A). The CPD and ACD solutions were prepared as described by Mollison (1972, pp. 686, 687).

\section{ANTIGLOBULIN SERA}

Anti-C4c and anti-C3b/c were purchased from Hoechst-Behringwerke Pharmaceuticals and used at a 1:50 dilution. The methods of preparation, characteristics, and anti-C3d antibody concentrations of R72 anti-C4d/3d, R84 anti-C3c/3d, R356 anti-C3d, and ZARCS monkey anti-C4d reagents have been described previously (Freedman and Mollison, 1976; Freedman et al., 1977; Chaplin et al., 1977). The reagents containing anti-C3d were used at anti-C3d antibody concentrations of $30-40 \mu \mathrm{g} / \mathrm{ml}$. A screening 'cocktail' antiserum was made up consisting of anti-C4c and anti-C3c (each at a final dilution of $1: 50$, that is $24 \mu \mathrm{g}$ antibody $/ \mathrm{ml}$ and $100 \mu \mathrm{g}$ antibody $/ \mathrm{ml}$ respectively) and of anti-C4d/3d (at a final dilution of $1: 15$, that is, $35 \mu \mathrm{g}$ anti-C3d/ml). AntiIgG was made by injecting highly purified IgG into rabbits. All antisera were heat-inactivated at $56^{\circ} \mathrm{C}$ for 30 minutes and repeatedly absorbed $(\times 6)$ 1014 
with a mixture of well-washed packed $\mathbf{A}_{1}, \mathbf{B}$, and $\mathbf{O}$ human red cells to remove heteroagglutinins. The antisera gave negative reactions with control trypsin-treated non-complement-coated red cells. The specificities of the reagents were shown by serological agglutination tests with monospecifically coated red cells and, except for anti-C4d for which no purified antigen was available, specificity was confirmed by immunoprecipitation and inhibition studies using fresh and aged human serum and purified complement components. Monospecific antiIgA and anti-IgM and polyspecific antiglobulin sera designed for tile or spin antiglobulin technique were purchased from commercial sources.

\section{PROCEDURES}

Standard serological techniques were used (Mollison, 1972). Cells were washed four times in phosphatebuffered saline (PBS), pH 7·4, before antiglobulin testing. The tile antiglobulin technique, using an opal tile at $23^{\circ} \mathrm{C}$, was used unless otherwise stated. Agglutination on the tile was read at 5 minutes and was scored on an arbitrary scale from 0 (negative) to $4+$ (maximal).

Tests for normal incomplete cold antibody were done using fresh serum, separated strictly at $37^{\circ} \mathrm{C}$. 1 vol of $2 \%$ group $O$ cells was incubated with 1 vol of serum at $0^{\circ} \mathrm{C}$ for 1 hour, washed $\times 3$ in PBS at $37^{\circ} \mathrm{C}$, and tested by spin antiglobulin technique against anticomplement sera. Appropriate controls were included. In all cases, complement uptake on the red cells was easily inhibited by prior incubation of the serum with an equal volume of undiluted secretor saliva at $23^{\circ} \mathrm{C}$ for 30 minutes. Saline agglutination tests and cold agglutinin titres were performed by standard techniques (Mollison, 1972). Serum immunoglobulins and C3 and C4 levels were determined by radial immunodiffusion, and antinuclear antibody was tested by immunofluorescence.

\section{Results}

\section{TESTS ON NORMAL SUBJECTS}

The red cells from 200 EDTA blood samples, maintained at $23^{\circ} \mathrm{C}$, from healthy blood donors were tested within 6 hours of collection for the presence of bound complement or IgG. No sample was agglutinated by the cocktail antiserum (anti-C4d/3d, anti-C4c, and anti-C3b/c) or by monospecific antiIgG. Fifteen of the above EDTA samples were maintained in their own serum at $4^{\circ} \mathrm{C}$, and aliquots were removed daily for direct antiglobulin testing with the cocktail antiserum. No agglutination was detected in up to seven days of study. Red cells from 15 samples of blood from healthy donors taken into CPD and from 10 samples taken into ACD were similarly tested. No agglutination with the cocktail antiserum was observed in any case on daily testing for seven days.

Aliquots of 10 normal healthy donor clotted blood samples were kept at $23^{\circ} \mathrm{C}$ and at $4^{\circ} \mathrm{C}$ for 6 hours. Red cells from two of the 10 samples maintained at $23^{\circ} \mathrm{C}$ and from five of the 10 samples maintained at $4^{\circ} \mathrm{C}$ were agglutinated by the cocktail antiserum, as well as by specific anti-C4d, anti-C4c, anti-C3c, and anti-C3d. Agglutination was weak but definite, ranging from $\frac{1}{2}+$ to $2+$. In no case were the cells agglutinated by anti-IgG.

\section{TESTS ON HOSPITAL PATIENTS}

Direct antiglobulin tests were performed on the red cells of 100 consecutive random EDTA blood samples from hospital patients within 4 hours of collection. In no case was IgG detected on the cell surfaces; $7 \%$ of the samples were agglutinated by the cocktail antiserum and were investigated further. Table 1 shows the agglutination reactions of the positive samples. Using the tile antiglobulin technique, agglutination with the cocktail varied from $1+$ to $3+$. All seven samples were agglutinated by monospecific anti-C3d or anti-C4d reagents. None of the cells was agglutinated by anti-IgG, -IgA, -IgM, $-\mathrm{C} 3 \mathrm{~b} / \mathrm{c}$, or $-\mathrm{C} 4 \mathrm{c}$. In none of the seven cases was agglutination detectable by the tile technique using commercial polyspecific antiglobulin reagents, and five out of seven were not agglutinated by the commercial reagents using the spin antiglobulin technique. Similar results were obtained in all cases in repeat tests using freshly taken EDTA samples maintained strictly at $37^{\circ} \mathrm{C}$.

Several of the patients were anaemic, and one (case B) had a slightly elevated reticulocyte count (see Table 2). No relationship to $\mathrm{ABO}$ or $\mathrm{Rh}$ blood groups was evident.

In six of the seven cases having a positive direct antiglobulin test, serum was available for examination. None showed abnormally potent normal incomplete cold antibody, and the cold agglutinin titres were normal in five out of six cases. In case B, the titre of the serum with adult cells at $4^{\circ} \mathrm{C}$ was borderline (256) but was normal at higher temperatures. In no case were cold agglutinins detected at $23^{\circ} \mathrm{C}$. In five out of six sera, no antibody was detectable by saline agglutination tests at $20^{\circ} \mathrm{C}$ or in the antiglobulin phase using untreated or pre-papainised commercial panel cells. The serum of case F agglutinated all panel cells (both adult and cord cells) in saline agglutination tests at $20^{\circ} \mathrm{C}$ but not in the antiglobulin phase. No antibody specificity could be identified.

Serum C3 and C4 levels were normal in all cases, and none of the six sera gave a positive antinuclear 
Table 1 Direct antiglobulin test agglutination reactions with the seven hospital patients

\begin{tabular}{|c|c|c|c|c|c|c|c|c|c|c|c|c|c|c|c|}
\hline \multirow[t]{3}{*}{ Case } & \multicolumn{6}{|c|}{ Commercial polyspecific AGS } & \multirow{3}{*}{$\begin{array}{l}\text { Anti- } \\
\operatorname{Ig} G\end{array}$} & \multirow{3}{*}{$\begin{array}{l}\text { Anti- } \\
\text { IgA }\end{array}$} & \multirow{3}{*}{$\begin{array}{l}\text { Anti- } \\
\text { IgM }\end{array}$} & \multirow{3}{*}{$\begin{array}{l}\begin{array}{l}\text { Anti- } \\
C 3 b / c\end{array} \\
1: 50^{*}\end{array}$} & \multirow{3}{*}{$\begin{array}{l}\begin{array}{l}\text { Anti- } \\
C 4 c\end{array} \\
1: 50\end{array}$} & \multirow{3}{*}{$\begin{array}{l}\text { Anti- } \\
C 4 d / 3 d \\
R 72 \\
1: 15\end{array}$} & \multirow{3}{*}{$\begin{array}{l}\text { Anti } \\
C 3 c / 3 d \\
R 84 \\
1: 16\end{array}$} & \multirow{3}{*}{$\begin{array}{l}\text { Anti- } \\
\text { C3d } \\
\text { R356 } \\
1: 30\end{array}$} & \multirow{3}{*}{$\begin{array}{l}\text { Anti- } \\
C 4 d \\
Z A R C S \\
1: 18\end{array}$} \\
\hline & \multicolumn{2}{|l|}{1} & \multicolumn{2}{|l|}{2} & \multicolumn{2}{|l|}{3} & & & & & & & & & \\
\hline & Tile & Spin & Tile & Spin & Tile & Spin & & & & & & & & & \\
\hline $\mathbf{A}$ & 0 & 0 & 0 & 0 & 0 & 0 & 0 & 0 & 0 & 0 & 0 & $2 \frac{1}{2}$ & $1 \frac{1}{2}$ & $1 \frac{1}{2}$ & $1 \frac{1}{2}$ \\
\hline B & 0 & 1 & 0 & 1 & 0 & 0 & 0 & 0 & 0 & 0 & 0 & 3 & $2 \mathrm{z}$ & $1 \frac{1}{8}$ & $2 \frac{1}{2}$ \\
\hline C & 0 & 0 & 0 & 0 & 0 & 0 & 0 & 0 & 0 & 0 & 0 & 2 & 1 & 0 & $\frac{1}{2}$ \\
\hline D & 0 & 0 & 0 & 0 & 0 & 0 & 0 & 0 & 0 & 0 & 0 & $1 \frac{1}{2}$ & 1 & 0 & $\frac{1}{2}$ \\
\hline $\mathbf{E}$ & 0 & 2 & 0 & 1 & 0 & $\frac{1}{2}$ & 0 & 0 & 0 & 0 & 0 & $1 \frac{1}{2}$ & 1 & $1 \frac{1}{2}$ & $\frac{1}{2}$ \\
\hline $\mathbf{F}$ & 0 & 0 & 0 & 0 & 0 & 0 & 0 & 0 & 0 & 0 & 0 & 2 & $1 \frac{1}{2}$ & $\frac{1}{2}$ & $\frac{1}{2}$ \\
\hline $\mathbf{G}$ & $\mathbf{0}$ & $\mathbf{0}$ & 0 & $\mathbf{0}$ & $\mathbf{0}$ & 0 & $\mathbf{0}$ & $\mathbf{0}$ & 0 & $\mathbf{0}$ & 0 & 3 & $1 \frac{1}{2}$ & 1 & 2 \\
\hline \multicolumn{16}{|l|}{ Control cells: } \\
\hline IgG sensitised & 3 & 3 & 3 & 3 & $2 \frac{1}{2}$ & 3 & 3 & $\mathbf{0}$ & $\mathbf{0}$ & 0 & $\mathbf{0}$ & 0 & $\mathbf{0}$ & 0 & $\mathbf{0}$ \\
\hline LIS cells $\dagger$ & 3 & 3 & 3 & 3 & 3 & 3 & 0 & 0 & 0 & 4 & 4 & 4 & $3 \frac{1}{2}$ & 3 & 3 \\
\hline C3d/4d cellsł & 2 & $2 \frac{1}{2}$ & $1 \frac{1}{2}$ & $2 \frac{1}{2}$ & $\mathbf{0}$ & $1 \frac{1}{2}$ & 0 & 0 & 0 & $\mathbf{0}$ & 0 & 4 & $3 \frac{1}{2}$ & 3 & 3 \\
\hline
\end{tabular}

AGS = antiglobulin sera.

*Dilutions of antiserum in PBS.

†LIS cells : red cells coated primarily with C4b and C3b via low-ionic-strength medium (Freedman and Mollison, 1976).

†C3d/4d cells : trypsinised LIS cells (Freedman and Mollison, 1976).

Table 2 Clinical details of the seven hospital patients with positive direct antiglobulin tests

\begin{tabular}{|c|c|c|c|c|c|c|c|}
\hline \multirow[t]{2}{*}{ Case } & \multirow[t]{2}{*}{ Sex/age } & \multirow{2}{*}{$\begin{array}{l}\text { Haemoglobin } \\
(g / d I)\end{array}$} & \multirow{2}{*}{$\begin{array}{l}\text { Reticulocytes } \\
\%\end{array}$} & \multicolumn{3}{|c|}{ Serum immunoglobulins $(g / l)$} & \multirow[t]{2}{*}{ Clinical diagnosis } \\
\hline & & & & $I g G$ & $I g M$ & $\operatorname{Ig} A$ & \\
\hline $\mathbf{A}$ & M43 & $13 \cdot 0$ & $0 \cdot 5$ & ND & ND & ND & $\begin{array}{l}\text { No diagnosis; + rheumatoid factor; } \\
\text { False + VDRL (? autoimmune disease) }\end{array}$ \\
\hline $\mathbf{B}$ & F56 & $9 \cdot 0$ & $2 \cdot 5$ & 14 & $>2 \cdot 5$ & $3 \cdot 7$ & $\begin{array}{l}\text { Acute leukaemia; pulmonary infection; } \\
\text { hypertension }\end{array}$ \\
\hline C & F76 & $9 \cdot 6$ & $1 \cdot 0$ & $12 \cdot 1$ & $1 \cdot 5$ & $2 \cdot 0$ & Pneumonia-responding to penicillin \\
\hline $\mathbf{E}$ & M31 & $14 \cdot 8$ & 0.5 & $15 \cdot 2$ & $>2 \cdot 5$ & $4 \cdot 3$ & Mallory-Weiss syndrome \\
\hline $\mathbf{F}$ & F73 & $10 \cdot 5$ & $0 \cdot 5$ & $17 \cdot 8$ & $>2 \cdot 5$ & $5 \cdot 7$ & Rheumatoid arthritis \\
\hline $\mathbf{G}$ & M79 & $12 \cdot 1$ & $1 \cdot 0$ & $10 \cdot 4$ & $1 \cdot 1$ & $2 \cdot 9$ & Carcinoma of colon; prostatic carcinoma \\
\hline \multicolumn{4}{|c|}{ Normal range } & $6-16$ & $0 \cdot 5-2 \cdot 0$ & $1 \cdot 2-4$ & \\
\hline
\end{tabular}

ND $=$ not done.

antibody test. Serum immunoglobulins were elevated in three cases (Table 2). Serum IgG was elevated in case E. Serum IgM was elevated in cases A, D, and E. Serum IgA was elevated in cases D and E.

The patients' clinical diagnoses are listed in Table 2. No definite relationship of diagnosis to complement fixation could be drawn in any patient, but in cases $A$ and $F$ there was a strong suspicion of underlying autoimmune disease. In case $B$, the patient was on alphamethyldopa for hypertension, but no IgG could be detected on the red cells. Case $C$ was on oral amplicillin $250 \mathrm{mg}$ four times a day. In none of the other cases was the patient on drugs associated with positive antiglobulin tests. Respiratory infections were present in cases $B$ and $C$ but could not be ascribed to Mycoplasma pneumoniae. Case E, blood group AB, had received 15 units of group $A$ blood (4 units as whole blood) 12 days before testing. Three of the cases (A, C, and F) were associated with malignancy.

Of a second 100 random EDTA bloods from hospital patients, $8 \%$ were agglutinated by the cocktail antiserum. Again the positive results were due to the presence of $\mathrm{C} 3 \mathrm{~d}$ and $\mathrm{C} 4 \mathrm{~d}$ on the red cells.

\section{Discussion}

The results support the previous suggestion (Garratty and Petz, 1976) that anticoagulated samples are the preferred method for collecting blood for direct antiglobulin testing. Red cells from the anticoagulated samples, whether refrigerated or not, did not have detectable complement fixed to their surfaces and did not result in positive direct antiglobulin tests using anticomplement antiglobulin sera. Red cells incubated in normal serum, that is, clotted samples, fixed complement on their surfaces at room temperature, probably due to normal incomplete cold (NIC) antibody or principle. This effect was more pronounced after refrigeration. In all cases similar reactions were obtained with anti-C3d and anti-C4d. Previous reports have indicated that 
NIC-cells have primarily C4 fixed to their surfaces (Dacie et al., 1957; Garratty and Petz, 1971). The test NIC-cells prepared in this study showed equally strong agglutination with anti-C3 and anti-C4 reagents, for example, $2+$ agglutination with anti$\mathrm{C} 4 \mathrm{c}$ and anti-C3b/c, and $3+$ agglutination with anti-C4d and anti-C3d. The relative strength of the reactions probably reflects the relative potencies of the respective antisera: the anti-C3d serum used in this study gave a twofold higher agglutination titre against control $\mathrm{C} 3 \mathrm{~d} / 4 \mathrm{~d}$ cells than did the anti-C4d serum. In no case was $\mathrm{C} 4 \mathrm{~d}$ detected on the red cells in the absence of C3d.

Dacie and Worlledge (1969) reported positive direct antiglobulin reactions using anticomplement sera in $8 \%$ of random hospital patients. In the current study, EDTA-treated red cells from $7 \%$ of hospital patients gave positive direct antiglobulin tests with anticomplement sera. Although in no case was a positive result suspected before the test, nor was a definite aetiology evident, the positive reactions may not represent false-positive reactions as such, since none of the $\mathbf{2 0 0}$ normal healthy subjects gave positive tests. In three out of six cases, subsequent testing revealed elevated serum immunoglobulins. In two out of six patients (cases $A$ and F) the positive antiglobulin reactions may represent additional evidence for autoimmune disease. In patient $\mathrm{E}$, the positive result may indicate complement sensitisation after transfusion and may represent an otherwise undetected transfusion incompatibility. None of the patients had overt haemolysis, and it does not appear possible to distinguish between these 'unexplained' positive antiglobulin tests without overt haemolysis and those positive results found in some cases of autoimmune haemolytic anaemia. Red cells from several patients with autoimmune haemolytic anaemia were tested with the above anticomplement sera, and serological results similar to those seen in the seven patients above were observed.

The antisera used in the study were potent reagents, for example, the anti-C4d/3d serum gave a titre of 2048 with control C3d/4d cells. The monospecific reagents also gave high titres with specific complement-coated control cells. At the dilutions used $(30-40 \mu \mathrm{g}$ anti-C3d $/ \mathrm{ml})$ all antisera gave $4+$ agglutination with appropriate control cells. That the antisera did not give positive reactions with any of the 200 normal healthy donors tested suggests that these antisera at least do not need to be further diluted to avoid false-positive results. Preliminary results in our laboratory indicate that an anti-C3d antibody concentration of $10-20 \mu \mathrm{g} / \mathrm{ml}$ may be optimal for the detection of abnormal amounts of C3d bound to red cells in vivo using the direct antiglobulin test (unpublished observations). Normal red cells taken into EDTA do have small amounts of C3d on their surfaces (Graham et al., 1976; Rosenfield and Jagathambal, 1978; Freedman and Massey, unpublished observations), and this normally present C3d may vary in amount in different normal, healthy individuals. It is felt, however, that the positive direct antiglobulin tests due to anticomplement described in the above patients are due to abnormal amounts of complement deposited on red cells and may be early markers of autoimmune disease.

The positive antiglobulin reactions observed in the hospital patients did not appear to be due to species antibodies, NIC, or other clinically insignificant cold antibodies or to drugs. Since no C3b or $\mathrm{C} 4 \mathrm{~b}$ was detected on the red cells, the positive reactions were probably due to red cell sensitisation in vivo rather than in vitro. It is suggested, therefore, that false-positive direct antiglobulin reactions should not be lightly dismissed and that patients should be further followed for other markers of autoimmune disease.

I thank Professor P. L. Mollison for much helpful advice and Mrs C. A. Johnson and Mr J. Wright for able technical assistance. This work was supported by funds from the Canadian Medical Research Council (grant MA-6693) and from the Ontario Ministry of Health (grant PR-658C).

\section{References}

Beck, M. L., Hicklin, B., and Pierce, S. R. (1976). Unexpected limitations in the use of commercial antiglobulin reagents. Transfusion, 16, 71-75.

Beck, M. L., and Marsh, W. L. (1977). Complement and the antiglobulin test (Letter). Transfusion, 17, 529.

Chaplin, H., Jr. (1973). Clinical usefulness of specific antiglobulin reagents in autoimmune hemolytic anemias. Progress in Hematology, 8, 25-49.

Chaplin, H., Jr., Freedman, J., and Hughes-Jones, N. C. (1977). Quantification of antibodies to the C3d subcomponents of human C3. Immunology, 32, 1007-1015.

Dacie, J. V., Crookston, J. H., and Christenson, W. N. (1957). 'Incomplete' cold antibodies: role of complement in sensitization of antiglobulin serum by potentially haemolytic antibodies. British Journal of Haematology, 3, 77-87.

Dacie, J. V., and Worlledge, S. M. (1969). Autoimmune hemolytic anemias. Progress in Hematology, 6, 82-120.

Freedman, J., Chaplin, H., and Mollison, P. L. (1977). Further observations on the preparation of antiglobulin reagents reacting with $\mathrm{C} 3 \mathrm{~d}$ and $\mathrm{C} 4 \mathrm{~d}$ on red cells. Vox Sanguinis, 33, 21-28.

Freedman, J., and Mollison, P. L. (1976). Preparation of red cells coated with $\mathrm{C} 4$ and $\mathrm{C} 3$ subcomponents and production of anti-C4d and anti-C3d. Vox Sanguinis, 31, 241-257. 
Garratty, G., and Petz, L. D. (1971). An evaluation of commercial antiglobulin sera with particular reference to their anticomplement properties. Transfusion, 11, 79-88.

Garratty, G., and Petz, L. D. (1976). The significance of red cell bound complement components in development of standards and quality assurance for the anticomplement components of antiglobulin sera. Transfusion, 16, 297-306.

Graham, H. A., Davies, D. M., Jr., Tigner, J. A., and Brower, C. E. (1976). Evidence suggesting that trace amounts of $\mathrm{C} 3 \mathrm{~d}$ are bound to most human red cells (Abstract). Transfusion, 16, 530.

Issitt, P. D., Issitt, C. H., and Wilkinson, S. L. (1974). Evaluation of commercial antiglobulin sera over a two-year period. Part II. Anti-IgG and anti-IgM levels and undesirable contaminating antibodies. Transfusion, 14, 103-108.

Lacey, J. T., and Cubbin, M. C. (1977). An assessment of commercial broad spectrum anti-human globulin reagents available in the United Kingdom. Medical Laboratory Sciences, 34, 201-212.

Mollison, P. L. (1972). Blood Transfusion in Clinical Medicine, 5th edition, pp. 394 and 420. Blackwell, Oxford.

Petz, L. D., and Garratty, G. (1978). Antiglobulin sera-past, present and future. Transfusion, 18, 257 268.

Rosenfield, R. E., and Jagathambal (1978). Antigenic determinants of $\mathrm{C} 3$ and $\mathrm{C} 4$ complement components on washed erythrocytes from normal persons. Transfusion, 18, 517-523.

Stratton, F., and Rawlinson, V. I. (1974). Preparation of test cells for the antiglobulin test. Journal of Clinical Pathology, 27, 359-367.

Requests for reprints to: $\mathrm{Dr}$ J. Freedman, Director, Blood Bank, St Michael's Hospital, 30 Bond Street, Toronto, Ontario M5B 1W8. 